\title{
Studies on the Regulation of Extracellular Enzyme Formation by Bacillus subtilis
}

\author{
By G. COLEMAN \\ Department of Biochemistry, The University, Sheffield, ro
}

(Accepted for publication 12 June 1967)

\begin{abstract}
SUMMARY
The progress of secretion of the extracellular enzymes ribonuclease, $\alpha$-amylase and proteinase by Bacillus subtilis, growing in a defined and in a complex medium, containing maltose, starch, glycerol or glucose as carbon source, was followed. In either medium and in the presence of any of the carbon sources the general characteristics of secretion of all three enzymes were the same. There was a low but definite production of exoenzyme from the moment the cells started to grow until the end of the logarithmic phase after which, when the rate of increase in cell mass was decreased, the rate of enzyme secretion increased to a high linear value which was maintained even into the stationary phase.

The results are discussed in relation to a possible regulatory mechanism which might account for the observed characteristics of extracellular enzyme secretion. A mechanism is proposed whereby exoenzyme m-RNA formation and hence enzyme production is limited during growth by a limitation of nucleic acid precursors caused by the depletion of the precursor pool during rapid ribosomal RNA synthesis. When the growth rate is decreased, ribosome synthesis is also decreased; the nucleic acid precursor pool may then increase in size, thereby removing the limitation so that exoenzyme m-RNA and protein may be formed at the maximum rate.
\end{abstract}

\section{INTRODUCTION}

No detailed study has been made of the mechanism which controls the production of extracellular enzymes by Bacillus subtilis. There are, however, several reports describing the characteristics of formation of the most important of these enzymes. Thus $\alpha$-amylase (Fukumoto, Yamamoto, Tsuru \& Ichikawa, 1957; Coleman \& Elliott, 1962) and ribonuclease (Nishimura \& Nomura, I959; Coleman \& Elliott, 1964) have been shown to lag behind cell growth, maximum accumulation of these enzymes occurring after the end of the logarithmic phase. Nomura, Maruo \& Akabori (1956), also studying $\alpha$-amylase formation, reported a distinct separation of several hours between the end of the logarithmic growth of $B$. subtilis, during which no enzyme secretion was observed, and the phase during which enzyme was secreted in significant amounts. They concluded that $\alpha$-amylase formation occurs only in old cells in which normal cellular multiplication no longer occurs. Fukumoto et al. (1957) studied the progress of proteinase secretion and reported that the production of this enzyme reached its peak before either maximum cell growth or $\alpha$-amylase formation. Coleman $\&$ Grant (1966) studied the characteristics of $\alpha$-amylase formation by $B$. subtilis in a defined medium containing different carbon sources. They showed that, irrespective 
of the carbon source used, $\alpha$-amylase was formed throughout the growth cycle, although the rate of production during the logarithmic phase was considerably less than after logarithmic growth has ceased. The present communication deals with an extension of the work on $\alpha$-amylase reported by Coleman \& Grant (I966) to ribonuclease and proteinase. The characteristics of formation of all three extracellular enzymes were studied in both defined and complex media, in the presence of different carbon sources. The results are discussed in relation to a possible regulatory mechanism which might account for the observed characteristics.

\section{METHODS}

Organism. The strain of Bacillus subtilis was supplied by Dr L. A. Underkofler (Takamine Laboratories Inc., Clifton, New Jersey, U.S.A.).

Media. The defined medium was as described by Coleman \& Grant (I966). The complex medium was obtained by replacing the amino acids and vitamins of the defined medium with $0.5 \%$ casein hydrolysate (British Drug Houses Ltd) $+0.05 \%$ yeast extract (Difco). The defined and the complex medium were both supplemented with either starch, maltose, glycerol or glucose at a concentration of $\mathrm{I} \%$, as carbon source. Both media were adjusted to $\mathrm{pH} 7 \cdot 2$ before autoclaving and before the addition of carbon source, in the usual manner. However, at the beginning of the experimental period the $\mathrm{pH}$ of the complete medium was 6.9 in every case.

Growth conditions. The organism was grown as described by Coleman \& Grant (1966).

Analytical methods. Culture tubes were taken at $2 \mathrm{hr}$ intervals over a period of $\mathrm{I} 4 \mathrm{hr}$, beginning early in the logarithmic phase. Each culture was centrifuged at $5000 \mathrm{~g}$ for $5 \mathrm{~min}$. and the supernatant fraction removed, this was retained and samples taken for enzyme assay. The dry weight of the bacterial pellet was determined (Coleman \& Elliott, 1962) from which the bacterial concentration was calculated as dry wt bacteria/ml. It should be noted that in expressing bacterial concentrations in terms of dry wt bacteria $/ \mathrm{ml}$. the assumption is made that all the organisms are viable although there is no unequivocal proof of this. The reason why this assumption is necessary is that under the conditions of the experiments the bacteria readily form clumps, particularly in the post-logarithmic phase, which prevents the determination of true viable counts. However, counting individual aggregates of 5-20 organisms in a PetroffHausser counting chamber gives a figure which corresponds very closely to the "viable count' of the preparation. Microscopic examination, both light and electron, together with heat-sensitivity tests showed that during the time course of these experiments the bacteria did not reach the stage of sporulation. Thus, as closely as can be determined, there is no evidence to suggest that all the bacteria in the preparations are not viable.

$\alpha$-Amylase assays were done as described by Coleman \& Elliott (1962).

Ribonculease was assayed as described by Coleman \& Elliott (1965).

Proteinase was assayed by what was essentially the method of Charney $\&$ Tomarelli (1947). The standard procedure was as follows: $1 \cdot 0 \mathrm{ml}$. samples of suitably diluted enzyme (supernatant fluid) preparations contained in test tubes $(\mathrm{I} .5 \mathrm{~cm} . \times 12.5 \mathrm{~cm}$.) were equilibrated at $25^{\circ}$. To each tube was added $\mathrm{r} \cdot \mathrm{O} \mathrm{ml}$. azocasein solution $(\mathrm{pH} 8 \cdot 3)$, also equilibrated at $25^{\circ}$, and the resulting reaction mixtures incubated at $25^{\circ}$ for I5 min. The reaction was stopped by the addition of $8 \mathrm{ml} .5 \%(\mathrm{w} / \mathrm{v})$ trichloroacetic 
acid and the precipitated protein (substrate) was filtered off by using Whatman no. 54. filter papers. Five-ml. samples of the supernatant fractions were taken and $0.5 \mathrm{ml}$. Io $\mathrm{N}-\mathrm{NaOH}$ added to each to develop the colour of the 'proteinase-solubilized' material. Extinctions were measured at $440 \mathrm{~m} \mu$ in a $\mathrm{I} \mathrm{cm}$. cuvette with a Unicam SP 500 spectrophotometer. All values were corrected for a zero time blank of $E_{440 \mathrm{~m} \mu}$ approx. $0 \cdot 040$. The method was standardized with 'Novo' crystalline Bacillus subtilis proteinase; I $\mu \mathrm{g}$. enzyme in the assay system produced a $\Delta E_{440 \mathrm{~m} \mu}$ of 0.0025 .

To bring this enzyme in line with $\alpha$-amylase and ribonuclease-that is, so that a unit of enzyme activity in each case represents the same amount of protein-the unit of proteinase activity was defined as the amount of enzyme which, under the standard conditions of the assay procedure, produced an increase in extinction at $440 \mathrm{~m} \mu$ of 0.0005 . The assay gave a linear relationship between enzyme concentration and extinction up to $\Delta E_{440 \mathrm{~m} \mu}$ of $0 \cdot 200$.

\section{RESULTS}

\section{Characteristics of extracellular enzyme formation in a defined medium}

The progress of bacterial growth and of proteinase, $\alpha$-amylase and ribonuclease secretion in a defined medium with I \% maltose as the carbon source is shown in Fig. I. The organism grew logarithmically until a concentration equiv. of $0.3 \mathrm{mg}$. dry wt. bacteria/ml. was reached. During the logarithmic phase a low rate of secretion of all three exoenzymes was observed. The logarithmic phase was followed by a long lag during which the bacterial concentration increased about threefold. Concomitant with the decrease in growth rate the rate of extracellular enzyme synthesis increased in each case, reaching a maximum which was maintained during the remainder of the experimental period. The units of enzyme activity are related to the same amount of enzyme protein in each case, so, whilst at the end of the experimental period the amount of ribonuclease and $\alpha$-amylase protein was about $\mathrm{I} \%$ and $25 \%$, respectively, of the amount of proteinase-protein, all three enzymes were nevertheless formed parallel to each other. This is illustrated in Fig. 2, where the results plotted in Fig. I are expressed as percentages of the values reached at the end of the experimental period.

These same characteristics-namely, logarithmic growth to a bacterial concentration equiv. $0.3 \mathrm{mg}$. dry wt bacteria $/ \mathrm{ml}$., followed by a long lag, together with a low rate of exoenzyme secretion in the logarithmic phase, followed by an increase to a high linear rate in the post-logarithmic phase, and maximum concentrations of enzyme in the medium in the ratio $I: 25: 100$ for ribonuclease: $\alpha$-amylase:proteinase, respectivelywere observed irrespective of whether maltose, starch, glycerol or glucose (at I \%) was included in the culture medium.

Differences were, however, observed in the presence of the different carbon sources in the doubling times during the logarithimic phase which were $2 \cdot 2 \mathrm{hr}$ with starch and maltose and $\mathrm{r} \cdot 6$ and $\mathrm{I} \cdot 7 \mathrm{hr}$, respectively, with glucose and glycerol. During the $\mathrm{I} 4 \mathrm{hr}$ experimental periods, in the case of starch, maltose and glycerol the $\mathrm{pH}$ value increased steadily by $0 \cdot 2-0 \cdot 3 \mathrm{pH}$ unit. With glucose, where the fastest doubling time was recorded, the $\mathrm{pH}$ value decreased by $0.2 \mathrm{pH}$ unit during the logarithmic phase and subsequently rose to the value of the other cultures by the end of the incubation.

Figure 3 shows the differential rates of ribonuclease formation in the presence of maltose, starch, glycerol and glucose as carbon sources. Similar sets of curves were obtained for $\alpha$-amylase (Coleman \& Grant, I966) and proteinase. All showed a low 
differential rate of exoenzyme formation during the logarithmic phase which increased after the end of the logarithmic phase to the same high level for each enzyme irrespective of the carbon source employed. The initial rates tended to an inverse relationship with the doubling times such that the greatest rates were observed with starch and maltose and the lowest with glucose. However, with glucose the lower rate may be connected in some way with the decrease of $\mathrm{pH}$ value due to acid formation. This may be a $\mathrm{pH}$ effect per se, or the decrease of $\mathrm{pH}$ value may simply reflect an accumulation of intermediates of glucose catabolism which lower the differential rate of exoenzyme production by catabolite repression.

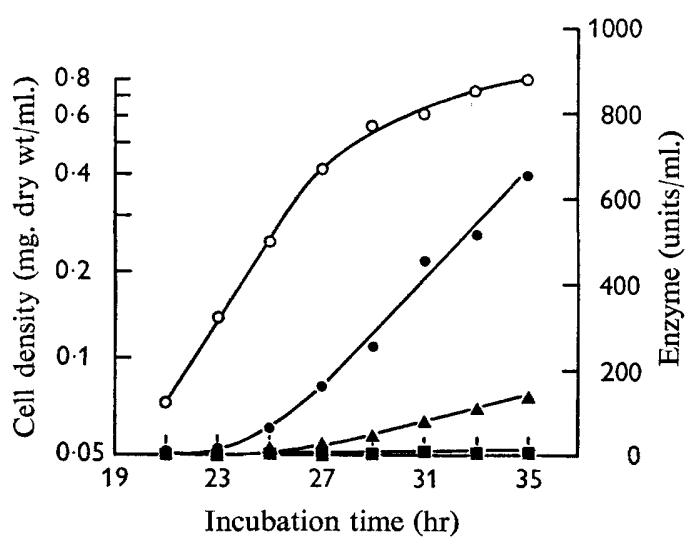

Fig. I

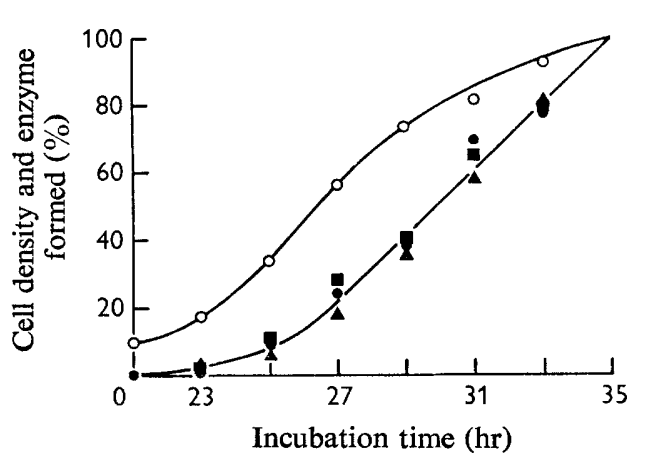

Fig. 2

Fig. I. Time courses of growth $(O)$ and of proteinase (O), $\alpha$-amylase ( $\Delta$ ) and ribonuclease $(\boldsymbol{E})$ secretion by Bacillus subtilis growing in a defined medium with $\mathrm{I} \%$ maltose as the carbon source.

Fig. 2. Progress of increase in cell density $(O)$ and secretion of proteinase $(\Theta), \alpha$-amylase $(\boldsymbol{A})$ and ribonuclease $(\boldsymbol{\Xi})$, each expressed as a percentage of the values at the end of the experimental period.

\section{Characteristics of extracellular enzyme formation in a complex medium}

Experiments parallel to those already described were done in which the organism was grown in a complex medium containing $0.5 \%$ casein hydrolysate $+0.05 \%$ yeast extract in place of the amino acids and vitamins of the defined medium. Figure 4 shows the time courses of growth and extracellular enzyme secretion in a complex medium with I \% maltose as the carbon source. It is apparent that the complex medium supported more growth and greater extracellular enzyme production than did the defined medium. With complex media logarithmic growth continued until a bacterial concentration equiv. I $\cdot 0 \mathrm{mg}$. dry wt bacteria $/ \mathrm{ml}$. was achieved, then after a lag during which the bacterial concentration doubled, a final stationary phase was quickly reached. During this stationary phase the exoenzymes continued to be secreted at the maximum rate and in a linear fashion. The ratios between the amounts of enzyme produced up to the end of the experimental period again, as in I \% maltose defined medium, were I:25:I00 for ribonuclease: $\alpha$-amylase:proteinase, respectively. The results plotted in Fig. 4, expressed as percentages of the final values, showed that the enzymes were again seen to be secreted in a parallel fashion (Fig. 5). 
These same relationships were also observed when the organism was grown in media supplemented with starch, glycerol or glucose. Thus the end of the logarithmic phase was reached at a bacterial concentration equiv. $\mathrm{I} \cdot \mathrm{O} \mathrm{mg}$. dry $\mathrm{wt}$ bacteria/ml. and a final stationary phase at $2.0 \mathrm{mg}$. dry $\mathrm{wt} / \mathrm{ml}$. in each case. However, although the enzymes were secreted parallel to each other the ratio between the amounts present in the complex culture media at the end of each experimental period showed a deviation that was not observed when the organism was grown in defined media. The greatest variation was observed in the glucose-grown culture where the ratio proteinase: $\alpha$-amylase:ribonuclease at the end of the experimental period was I00: $10 \cdot 7: 0 \cdot 8$.

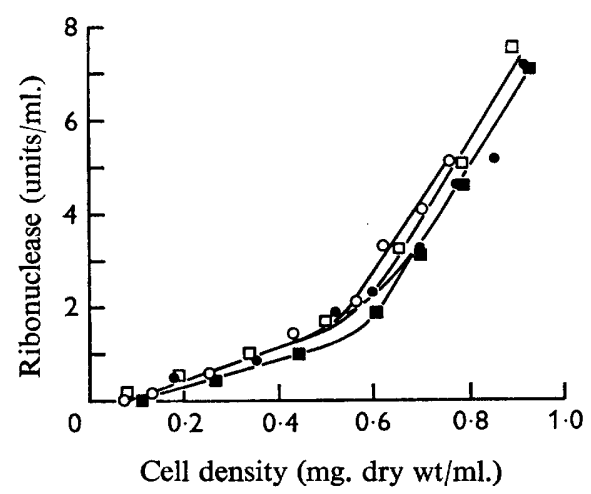

Fig. 3

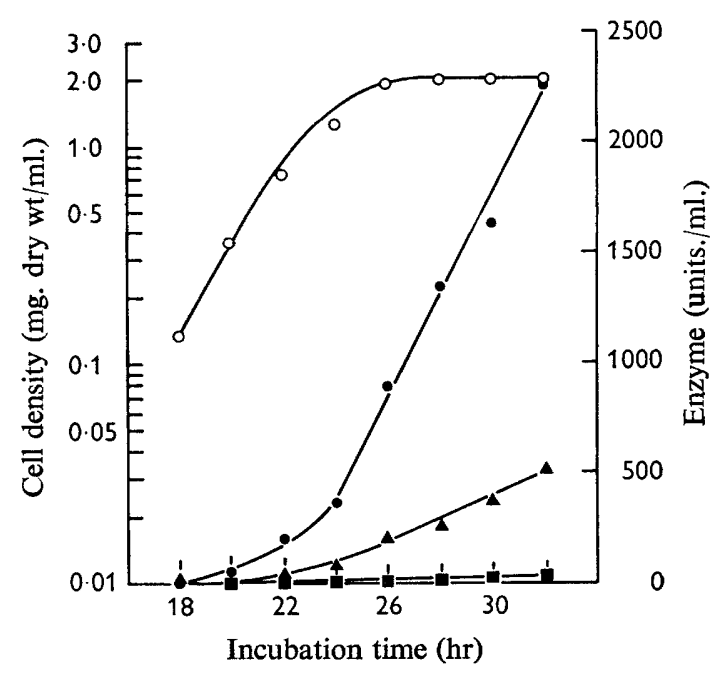

Fig. 4

Fig. 3. Differential rate of ribonuclease secretion by Bacillus subtilis growing in a defined medium with maltose $(O)$, starch $(O)$, glycerol $(\square)$ or glucose $(\square)$, at a level of $\mathbf{I} \%$ as carbon source.

Fig. 4. Time courses of growth $(O)$ and of proteinase $(\Theta), \alpha$-amylase $(\boldsymbol{\Delta})$ and ribonuclease (i) secretion by Bacillus subtilis growing in a complex medium with $\mathrm{I} \%$ maltose as the carbon source.

In the complex medium growth was faster than in the defined medium in all cases except in the presence of glycerol, where a doubling time of $2.0 \mathrm{hr}$ was recorded. Doubling times of $\mathrm{I} \cdot 3, \mathrm{I} \cdot 6$ and $\mathrm{I} \cdot 4 \mathrm{hr}$ were observed when the organism was grown in the presence of starch, maltose or glucose, respectively.

In the maltose- and starch-containing media the $\mathrm{pH}$ value increased during the $\mathrm{I} 4 \mathrm{hr}$ experimental period by $0 \cdot \mathrm{I}-0 \cdot 2 \mathrm{pH}$ unit, whilst with glucose there was a decrease of $0.4 \mathrm{pH}$ unit during the logarithmic phase, followed by an increase of $0.6 \mathrm{pH}$ unit to the end of the experimental period. With glycerol the $\mathrm{pH}$ decreased by $0.2 \mathrm{pH}$ unit after $4 \mathrm{hr}$, and $6 \mathrm{hr}$ later increased by $0.2 \mathrm{pH}$ unit to the initial value, which was then maintained during the remainder of the experimental period.

The differential rates of synthesis of ribonuclease, $\alpha$-amylase and proteinase in the presence of starch, maltose, glucose and glycerol, as carbon sources, showed the same general characteristics as were observed when the organism was grown in the defined medium; a representative set of curves is shown in Fig. 6 . Thus there was a low initial 
differential rate of formation in each case, which increased after the end of the logarithmic phase. However, in the complex medium final rates approaching infinity were achieved since the enzymes were secreted at the maximum rate even after the stationary phase had been reached and there was no further net increase in cell mass.

The initial differential rates of synthesis showed the same trend as in the defined medium with the highest values for maltose and starch and the lowest for glucose. However, in this case no simple relationship was observed between the initial differential rates and the doubling times. Again, the lower rate in the presence of glucose might be ascribed to a lowering of the $\mathrm{pH}$ value or to catabolite repression. Experiments were therefore made to test this.

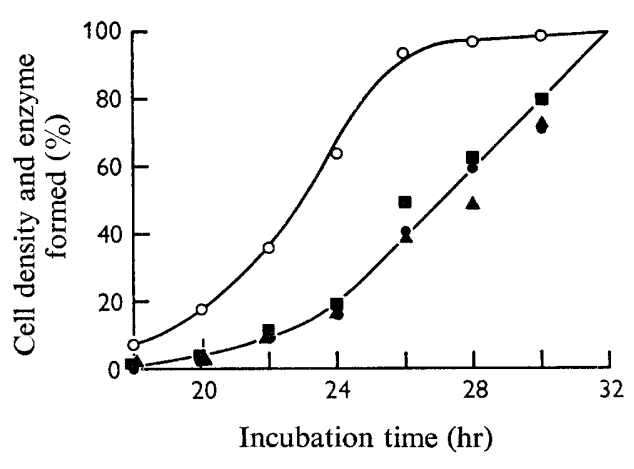

Fig. 5

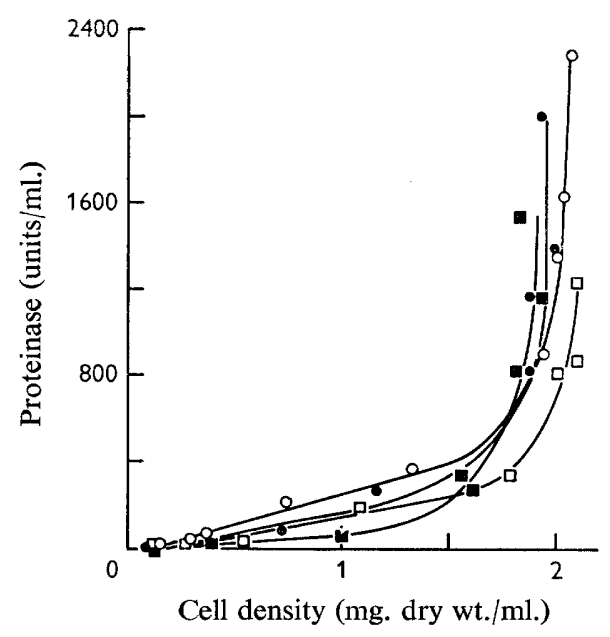

Fig. 6

Fig. 5. Progress of increase in cell density $(O)$ and secretion of proteinase ( $(\bullet), \alpha$-amylase $(\boldsymbol{A})$ and ribonuclease $(\boldsymbol{\omega})$, each expressed as a percentage of the values at the end of the experimental period.

Fig. 6. Differential rate of proteinase secretion by Bacillus subtilis growing in a complex medium with maltose $(\bigcirc)$, starch $(\mathbf{O})$, glycerol $(\square)$ or glucose $(\boldsymbol{\square})$, at a level of $\mathrm{I} \%$ as carbon source.

\section{Effect of maintaining constant $p H$ value on the secretion of exoenzymes during logarithmic growth in a glucose-containing medium}

The effect of the decrease of the $\mathrm{pH}$ value caused by acid formation, during growth in a glucose-containing complex medium, on extracellular enzyme secretion was examined by two experiments done in parallel. In the first experiment, extracellular enzyme secretion was followed through the logarithmic phase, the culture being allowed to maintain its own $\mathrm{pH}$ value, which was measured at hourly intervals. In the parallel experiment the $\mathrm{pH}$ value was adjusted hourly to the initial value by adding Io $\mathrm{N}-\mathrm{NaOH}$, so that the $\mathrm{pH}$ value did not fluctuate by more than $0 \cdot \mathrm{I} \mathrm{pH}$ unit. The progress of extracellular enzyme formation was again followed through the logarithmic phase. The results are shown in Table I. It can be seen that $4 \mathrm{hr}$ from the beginning of the experiment the $\mathrm{pH}$ value of the culture to which no additions of alkali were made had reached a minimum value, having decreased by $0.5 \mathrm{pH}$ unit, and during the following $4 \mathrm{hr}$ period the $\mathrm{pH}$ value increased by $0.3 \mathrm{pH}$ unit. 
In spite of the decrease in $\mathrm{pH}$ value of the unadjusted culture there was no significant difference between the amounts of enzyme secreted with and without $\mathrm{pH}$ adjustment during the first $4 \mathrm{hr}$. Subsequently, the amounts of extracellular enzyme secreted tended to be slightly higher in all cases where the $\mathrm{pH}$ value was kept constant. The results of the two experiments were not significantly different. Any gross effects on the initial differential rates of secretion of extracellular enzymes cannot be ascribed to the decrease in $\mathrm{pH}$ value during logarithmic growth in the presence of glucose.

Table I. Effect of maintaining constant $\mathrm{pH}$ on the secretion of exoeozymes by Bacillus subtilis growing on a $I_{\%} \%$ glucose-complex medium

The $\mathrm{pH}$ of both series was measured at hourly intervals and the 'constant $\mathrm{pH}$ ' culture was maintained at $\mathrm{pH} 6 \cdot 8-6 \cdot 9$ by the addition of $\mathrm{ION}-\mathrm{NaOH}$.

\begin{tabular}{|c|c|c|c|c|c|c|c|}
\hline \multirow{2}{*}{$\begin{array}{c}\text { Incubation } \\
\text { time } \\
\text { (hr) }\end{array}$} & \multirow{2}{*}{$\begin{array}{c}\text { pH of } \\
\text { control } \\
\text { culture } \\
\text { (no pH } \\
\text { adjustment) }\end{array}$} & \multicolumn{2}{|c|}{$\begin{array}{l}\text { Ribonoculease } \\
\text { (units/ml.) }\end{array}$} & \multicolumn{2}{|c|}{$\begin{array}{l}\alpha \text {-Amylase } \\
\text { (units } / \mathrm{ml} \text {.) }\end{array}$} & \multicolumn{2}{|c|}{$\begin{array}{l}\text { Proteinase } \\
\text { (units } / \mathrm{ml} \text {.) }\end{array}$} \\
\hline & & Control & pH 6.9 & Control & pH 6.9 & Control & pH 6.9 \\
\hline $0^{*}$ & $6 \cdot 9$ & 0.0 & 0.0 & 0 & o & 0 & o \\
\hline 2 & $6 \cdot 6$ & 0.4 & 0.6 & I & I & 20 & 32 \\
\hline 4 & $6 \cdot 4$ & $1 \cdot 6$ & $\mathrm{I} \cdot 9$ & II & I3 & 76 & 76 \\
\hline 6 & 6.5 & 3.5 & $4 \cdot 2$ & 30 & 34 & 216 & 228 \\
\hline 8 & $6 \cdot 7$ & 5.6 & $7 \cdot 2$ & 69 & 74 & 436 & 476 \\
\hline
\end{tabular}

* Zero time corresponds to a point in the logarithmic phase ( $14 \mathrm{hr}$ ) when growth is just apparent.

\section{Effect of adding extra carbon source to a culture at the beginning of the stationary phase on the subsequent secretion of extracellular enzymes}

The lower differential rates of exoenzyme formation during the logarithmic phase in the presence of glucose thus cannot be accounted for by the decrease of $\mathrm{pH}$ value which resulted from the accumulation of acids in the medium. A further possible explanation is that the accumulated intermediates of carbohydrate breakdown might have given rise to catabolite repression during the logarithmic phase, which was removed during the post-logarithmic phase as the repressing metabolites were further metabolized. Mandelstam (196r, I962) made detailed studies on catabolite repression and concluded that any compound which an organism can use as a source of carbon and energy can cause catabolite repression of a sensitive system under the right conditions. Namely, when growth is prevented by the omission of an essential ingredient from the medium then in the presence of a carbon source intermediates can accumulate and conditions will favour the build-up of the repressing catabolite to a value at which it will exert an effect. To determine whether exoenzyme formation in Bacillus subtilis was subject to catabolite repression a culture in $\mathrm{I} \%$ maltose complex medium was taken in the stationary phase at $28 \mathrm{hr}$ which (as can be seen from Fig. 4) was expected to secrete exoenzymes at the maximum rate for at least $4 \mathrm{hr}$. An extra carbon source, maltose, glucose or glycerol, was dissolved in samples of culture and the progress of exoenzyme formation followed for a further $3 \mathrm{hr}$ and the values compared with a control to which no extra carbon source had been added. The results (Table 2) showed that identical results were obtained with or without extra maltose, and in each case an insignificant increase in bacterial dry weight of $3-4 \%$ was observed over the $3 \mathrm{hr}$ period. If the formation of $\alpha$-amylase, ribonuclease and proteinase, which are secreted parallel, were 
subject to catabolite repression, then according to Mandelstam (I96I, I962) the enzyme concentrations achieved in the presence of excess maltose should have been decreased; clearly this was not so.

Table 2. Effect of adding extra carbon source on exoenzyme secretion by a stationary phase culture of Bacillus subtilis in a $I \%$ maltose-complex medium

\begin{tabular}{|c|c|c|c|c|c|c|c|c|c|}
\hline \multirow[b]{3}{*}{ Addition } & \multicolumn{9}{|c|}{ Increase in exoenzymes } \\
\hline & \multicolumn{3}{|c|}{$\begin{array}{l}\text { ribonuclease } \\
\text { (units } / \mathrm{ml} \text {.) }\end{array}$} & \multicolumn{3}{|c|}{$\begin{array}{l}\alpha \text {-amylase } \\
\text { (units } / \mathrm{ml} \text {.) }\end{array}$} & \multicolumn{3}{|c|}{$\begin{array}{l}\text { proteinase } \\
\text { (units } / \mathrm{ml} \text { ) }\end{array}$} \\
\hline & $\mathrm{I} \mathrm{hr}$ & $2 \mathrm{hr}$ & $3 \mathrm{hr}$ & I hr & $2 \mathrm{hr}$ & $3 \mathrm{hr}$ & I hr & $2 \mathrm{hr}$ & $3 \mathrm{hr}$ \\
\hline None $(3 \%)$ & $2 \cdot 6$ & $5 \cdot 7$ & $4 \cdot 6$ & 63 & 114 & 171 & 150 & 300 & 380 \\
\hline Maltose $(4 \%)$ & $2 \cdot 6$ & $5 \cdot 6$ & $4 \cdot 6$ & 56 & 104 & 158 & 150 & 280 & 380 \\
\hline Glycerol (15\%) & $2 \cdot 6$ & $5 \cdot 4$ & $6 \cdot I$ & $5 \mathrm{I}$ & 83 & II 4 & 110 & 240 & 310 \\
\hline \multirow[t]{2}{*}{ Glucose $(16 \%)$} & $\mathbf{I} \cdot 8$ & $4 \cdot 5$ & $6 \cdot 4$ & $5 \mathrm{I}$ & 76 & 113 & 170 & 240 & 340 \\
\hline & \multicolumn{3}{|c|}{$\begin{array}{l}\text { (Zero time* level } \\
\text { I0.3 units } / \mathrm{ml} \text {.) }\end{array}$} & \multicolumn{3}{|c|}{$\begin{array}{l}\text { (Zero time level } \\
239 \text { units } / \mathrm{ml} \text {.) }\end{array}$} & \multicolumn{3}{|c|}{$\begin{array}{l}\text { (Zero time level } \\
\text { I210 units/ml.) }\end{array}$} \\
\hline
\end{tabular}

* Zero time corresponds to $28 \mathrm{hr}$ incubation at which time the carbon supplements were added to a final concentration of $\mathrm{I} \%$, in each case. The increases in cell mass observed over the $3 \mathrm{hr}$ experimental period are shown in parentheses.

Table 3. Effect of adding chloramphenicol on exoenzyme secretion by postlogarithmic phase culture of Bacillus subtilis in a $x^{\%}$ maltose-complex medium

\section{Addition}

None

Chloramphenicol (10 $\mu \mathrm{g} . / \mathrm{ml}$.)

Chloramphenicol (100 $\mu \mathrm{g} . / \mathrm{ml}$.)
Increase in exoenzymes

$\overbrace{\begin{array}{c}\text { ribonuclease } \\ \text { (units } / \mathrm{ml} \text { ) }\end{array}}^{\begin{array}{c}\alpha \text {-amylase } \\ \text { (units } / \mathrm{ml} \text { ) }\end{array}} \begin{gathered}\text { proteinase } \\ \text { (units } / \mathrm{ml} \text { ) }\end{gathered}$

$$
\begin{aligned}
& 4.45 \text { (-) } \\
& 0.0(100) \\
& 0.0 \text { (100) } \\
& 124(-) \\
& 6 \text { (95) } \\
& \text { o (I00) } \\
& 380(-) \\
& 28 \text { (93) } \\
& \text { O (IOO) }
\end{aligned}
$$

Zero time corresponds to $24 \mathrm{hr}$ incubation at which time $0.01 \mathrm{ml}$. and $0.1 \mathrm{ml}$. of an aqueous solution of chloramphenicol ( $5 \mathrm{mg}$./ $/ \mathrm{ml}$.) were added to $5 \mathrm{ml}$. samples of culture. Incubation was continued for a further $3 \mathrm{hr}$ period. The figures in parentheses show the percentage inhibition of enzyme formation by chloramphenicol over the $3 \mathrm{hr}$ period of the experiment.

When the added carbon source was glucose or glycerol greater deviation from the control values were observed, but this might be accountable to the accompanying significant increase in bacterial mass in the presence of these carbon sources. In relation to the actual amounts of enzyme in the cultures (the $28 \mathrm{hr}$ zero time values were extremely high) these deviations amount to little more than experimental error. The results of this experiment therefore gave no support for the belief that catabolite repression played a part in controlling the extracellular enzyme formation.

\section{Effect of adding chloramphenicol at the beginning of the post-logarithmic phase on the subsequent secretion of extracellular enzymes}

The secretion of ribonuclease and $\alpha$-amylase by washed suspensions of postlogarithmic Bacillus subtilis was shown to involve de novo synthesis and not liberation 
or activation of preformed enzyme (Coleman \& Elliott, 1962, 1965). However, this work was not extended to proteinase. It was desirable to ascertain that the apperance of all three exoenzymes in the post-logarithmic phase, under the conditions of the present experiments, represented the formation of new protein and so the sensitivity of their secretion to chloramphenicol, a specific inhibitor of protein synthesis, was examined.

Chloramphenicol was added to a $24 \mathrm{hr}$ post-logarithmic culture of Bacillus subtilis grown in a $\mathrm{I} \%$ maltose-complex medium which was then incubated for a further $3 \mathrm{hr}$. The changes in extracellular enzyme levels in the presence and absence of chloramphenicol were determined over the $3 \mathrm{hr}$ experimental period. The results are shown in Table 3, where it can be seen that there was over $90 \%$ inhibition of the further secretion of all three enzymes by Io $\mu \mathrm{g} . / \mathrm{ml}$. of chloramphenicol; the inhibition was complete when the chloramphenicol was increased to $100 \mu \mathrm{g}$. $/ \mathrm{ml}$. This result is consistent with the appearance of all these enzymes involving de novo protein synthesis.

\section{DISCUSSION}

Before considering the implications of the results obtained in the present work it is expedient to consider relevant data obtained during earlier work. Coleman \& Elliott ( 1965 ) compared the formation of $\alpha$-amylase and ribonuclease in washed suspensions of post-logarithmic Bacillus subtilis. It was found that the appearance of both these enzymes in the medium had the characteristics of protein synthesized de novo during the period of secretion. In the earlier work the effect of actinomycin D on the formation of $\alpha$-amylase and ribonuclease was examined and evidence was obtained that a stable messenger RNA was involved in ribonuclease synthesis, whilst $\alpha$-amylase had an unstable messenger. These conclusions can be used to explain the different shapes of the progress curves of formation of the two enzymes in suspensions of washed bacteria.

Coleman \& Elliott (1965) observed that when post-logarithmic phase bacteria, in a I $\%$ maltose casein hydrolysate medium and producing $\alpha$-amylase and ribonuclease linearly, were suspended in new medium then ribonuclease was formed linearly, but at a rate $50 \%$ higher than previously and for at least $3 \mathrm{hr}$. By contrast, the rate of $\alpha$-amylase formation was drastically decreased, but after a $2 \mathrm{hr}$ lag it was again secreted linearly at the same rate as in the post-logarithmic phase culture. Over the $3 \mathrm{hr}$ experimental period there was an increase in bacterial mass of $90 \%$ in the washed suspension as compared with the original culture in which there was a $30 \%$ increase in bacterial mass over the same period.

It is obvious that as the bacteria are transferred from old medium, which is limiting in some nutrient, to new medium the culture will undergo a 'shift-up' transition with the concomitant formation of new ribosomes to enable growth to take place at a faster rate (Neidhardt \& Fraenkel, I96I; Schaechter, 196I). During the transition the inevitable drain on the pools of RNA and protein precursors will occur as ribosomes are preferentially synthesized. However, during this same period ribonuclease is formed at a faster rate than previously, indicating that there is no shortage of protein precursors for the translation of the stable ribonuclease messenger. On the other hand, the rate of $\alpha$-amylase formation is reduced and since there appears to be no shortage of protein precursors then the synthesis is probably limited by the reduction in nucleic acid precursor material, necessary for the formation of unstable m-RNA, due to its 
increased use during the preferential ribosome formation in accelerating growth conditions.

The present study of the characteristics of the formation of the three extracellular enzymes, $\alpha$-amylase, ribonuclease and proteinase, over the whole of the growth cycle, shows that irrespective of the medium used, defined or complex supplemented with either maltose, starch, glycerol or glucose, the enzymes are secreted parallel to each other, and although the amounts of each differ they approximate to a constant ratio to each other. A low differential rate of secretion is observed during the logarithmic phase of growth which undergoes a dramatic increase in the post-logarithmic phase.

Consideration of the whole of the data discussed above permits a regulatory mechanism to be described in terms of 'competition' at the level of the nucleic acid precursor pool.

Thus during logarithmic growth the nucleic acid precursor pool is depleted by the irreversible removal of material for ribosome synthesis (Stent, 1966) and to a lesser extent transfer RNA synthesis. The remaining nucleic acid precursors in the depleted pool are available for the formation of m-RNA involved in the synthesis of necessary enzymes and other proteins and will, in general, be removed and returned to the pool as described by Levinthal, Fan, Higa \& Zimmermann (1963). During this phase the precursors available for exoenzyme m-RNA synthesis, which is not obligatory for growth, will be strictly limited.

After the end of the logarithmic phase a slowing down of ribosome synthesis results in less drain on the RNA precursor pool and, further, ribosome 'turnover' contributes towards replenishing the pool. The net result of slowing growth will be a greatly increased pool available for m-RNA synthesis permitting increased exoenzyme formation (Ben-Hamida \& Schlessinger, 1966).

The observed characteristics can be explained in terms of such a mechanism provided that exoenzymes are produced in amounts sufficient to tax the organisms' anabolic resources. This is, in fact, the case and the increase in exoenzyme protein formation on passing from logarithmic to post-logarithmic growth conditions approximates to the reduction in cellular protein synthesis observed during the same transition.

Other mechanisms of control based on induction (Coleman \& Grant, I966), repression (Mandelstam, I96I, I962; Jacob \& Monod, I96I; Cline \& Bock, I966) and modulation (Stent, 1964) were considered but not one of them was as satisfactory in accounting for the experimental results as the simple model discussed. Thus if it is considered that the exoenzymes are formed constitutively with an overriding effect due to a limitation in nucleic acid precursors brought about by the potential for their synthesis on a massive scale then the characteristics of exoenzyme secretion are readily explained.

\section{REFERENCES}

Ben-Hamida, F. \& Schlessinger, D. (1966). Synthesis and breakdown of ribonucleic acid in Escherichia coli starving for nitrogen. Biochim. biophys. Acta $119,183$.

Charney, J. \& Tomarelli, R. M. (I947). A colorimetric method for the determination of the proteolytic activity of duodenal juice. J. biol. Chem. I7I, $50 \mathrm{I}$.

Cline, A. L. \& Bock, R. M. (1966). Translational control of gene expression. Cold Spr. Harb. Symp. quant. Biol. 3r, $32 \mathrm{I}$.

Colmman, G. \& Elliotr, W. H. (1962). Studies on $\alpha$-amylase formation by Bacillus subtilis. Biochem. $J .83,256$.

Coleman, G. \& ElliotT, W. H. (1964). Stimulation of extracellular ribonuclease formation in $B$. subtilis by actinomycin D. Nature, Lond. 202, 1083. 
Coleman, G. \& Elliott, W. H. (1965). Extracellular ribonuclease formation in Bacillus subtilis and its stimulation by actinomycin D. Biochem. J. $95,699$.

Coleman, G. \& Grant, M. A. (1966). Characteristics of $\alpha$-amylase formation by Bacillus subtilis. Nature, Lond. 2II, 306.

Funumoto, J., Yamamoto, T., Tsuru, D. \& Ichikawa, K. (1957). Some problems on bacterial amylase and proteinase production. Proc. int. Symp. Enzyme Chemistry, Tokyo and Kyoto, p. 479. London: Pergamon Press Ltd.

JACOB, F. \& MONOD, J. (I96I). Genetic regulatory mechanisms in the synthesis of proteins. J. molec. Biol. 3, 3 I 8.

Levinthal, C., Fan, D. P., Higa, A. \& Zimmermann, R. A. (I963). The decay and protection of messenger RNA in bacteria. Cold Spr. Harb. Symp. quant. Biol. 28, 183 .

MANDELSTAM, J. (1961). Induction and repression of $\beta$-galactosidase in non-growing Escherichia coli. Biochem. J. 79, 489 .

Mandelstam, J. (I962). The repression of constitutive $\beta$-galactosidase in Escherichia coli by glucose and other carbon sources. Biochem. J. 82, 489.

Neidhardt, F. C. \& FraenKel, D. G. (I96I). Metabolic regulation of RNA synthesis in bacteria. Cold. Spr. Harb. Symp. quant. Biol. 26, 63.

Nishimura, S. \& Nomura, M. (1959). Ribonuclease of Bacillus subtilis. J. Biochem., Tokyo 46, I6I. Nomura, M., Maruo, B. \& AKabori, S. (1956). Studies on amylase formation by Bacillus subtilis. I. Effect of high concentrations of polyethylene glycol on amylase formation by Bacillus subtilis. J. Biochem. Tokyo 43, I43.

SCHAEChTER, M. (I96I). Patterns of cellular control during unbalanced growth. Cold Spr. Harb. Symp. quant. Biol. 26, 53.

Stent, G. S. (1964). The operon: on its third anniversary. Science, N.Y. 144, 816.

Stent, G. S. (1966). Genetic transcription. Proc. R. Soc. B I64, I8I. 